\title{
Quiz and Games as Previous Knowledge Organizers: A Medical Training Experience Report
}

\section{José Carlos Souza', Iane Franceschet de Sousa ${ }^{2}$, Rafaela Palhano Medeiros Penrabel ${ }^{3}$, Patrícia Alves de Souza4 ${ }^{4}$ (D) Eduardo Henrique Bondarczuk ${ }^{4}$}

${ }^{1}$ Curso de Medicina, Universidade Estadual de Mato Grosso do Sul, Campo Grande, Brasil

${ }^{2}$ Departamento de Ciências da Saúde, Universidade Federal de Santa Catarina, Araranguá, Brasil

${ }^{3}$ Curso de Medicina, Universidade Anhanguera Uniderp, Campo Grande, Brasil

${ }^{4}$ Curso de Medicina, Universidade do Plantalto Catarinense, Lages, Brasil

Email: josecarlossouza@uol.com.br, ianefran@gmail.com,rafapenrabel@hotmail.com, passpb@gmail.com, ehb2707@gmail.com

How to cite this paper: Souza, J. C., de Sousa, I. F., Penrabel, R. P. M., de Souza, P. A., \& Bondarczuk, E. H. (2020). Quiz and Games as Previous Knowledge Organizers: A Medical Training Experience Report. Creative Education, 11, 68-76.

https://doi.org/10.4236/ce.2020.111005

Received: August 13, 2019

Accepted: January 13, 2020

Published: January 16, 2020

Copyright $\odot 2020$ by author(s) and Scientific Research Publishing Inc. This work is licensed under the Creative Commons Attribution International License (CC BY 4.0).

http://creativecommons.org/licenses/by/4.0/

\begin{abstract}
Introduction: Previous knowledge organizers are powerful didactic tools that allow maximizing the meaningful learning process. Objective: To report on the application of quizzes and games called "Brain Quiz and Games". Method: In the Medical School of the Mato Grosso do Sul State University (UESM), Brazil, during the Perception, Awareness and Emotion module, students performed two quizzes and two games during answering questions both individually and in groups. Descriptive analysis of the results was performed. The results showed that the dynamics stimulated the use of agile and correct reasoning, so necessary for a good medical practice. Students describe reports of motivation in the activities, which reflected in the good student performance in the final grades of the module. The activity of "Brain Quiz and Games" stimulated the advance study of the module content and the creation of subsumers in the cognitive structure of the students. Innovative activities, such as this, should be fostered, as they help students acquire knowledge.
\end{abstract}

\section{Keywords}

Medical Education, Learning, Problem Based Learning

\section{Introduction}

Currently, the National Curriculum Guidelines (NCG) for undergraduate medical programs in Brazil advocates the use of student-centered teaching-learning 
methods that favor self-learning and metacognitive processes for the occurrence of effective learning (Brasil, 2014; Dantas \& Rodrigues, 2013).

It is necessary to understand that the student learns significantly, when new information or new knowledge (a concept, an idea, a proposition, models or formulas) begins to mean something to him, when the learner can explain situations in his own words, when he becomes capable to solve new problems, in other words, when they understand their meaning (Moreira, 2013).

Meaningful learning relates new information to others with which the student is already familiar, in a non-arbitrarily and substantively (nonliteral) way (Ausubel et al., 1980).

A new knowledge to be related non-arbitrarily means that there was a relationship between the material used in the teaching process (a potentially meaningful material) and some specifically relevant concepts when these are already present in the learner's cognitive structure, which Ausubel called subsumers concepts. These new concepts, as they begin to form part of the cognitive structure of the learner, will be stored substantively (nonliteral). In other words, what one learns is the substance of new knowledge, not an exact and predetermined set of words used to represent it (Moreira, Caballero, \& Rodriguez, 1997).

It is possible to resort to previous organizers in order to assist in this process, which constitutes introductory materials presented prior to the learning material itself. A previous organizer prepares the ground for a new information incoming, activating memories, highlighting concepts and previous knowledge that the student has and that it could be used to anchor new information (Ribeiro, Silva, \& Koscianski, 2012).

Using prior organizers is a strategy for manipulating, deliberately, the cognitive structure in order to facilitate the meaningful learning. Previous organizers are introductory materials presented before the very material to be learned. Unlike summaries, which are generally presented at the same level of abstraction, generality and inclusiveness by simply highlighting certain aspects of the subject, organizers are presented at a higher level of abstraction, generality and inclusiveness (Moreira \& Masini, 1982).

Agra and collaborators point out that, in addition to using previous organizers, the student's willingness to learn is critical for meaningful learning to occur (Agra et al., 2017). This corroborates the theoretical basis of andragogy, establishing motivation as a condition for adult learning, allowing consideration of appropriate learning and teaching strategies for adult students (Taylor \& Hamdy, 2013).

Changes are taking place in health education and vocational training due to the introduction of active methodologies in the teaching-learning process in Brazilian higher education institutions. These active learning methodologies, such as Problem-Based Learning (PBL), are used to help medical students gain more relevant knowledge compared to traditional teaching (Dias-Lima et al., 2019). 
Thus, several medical courses that already use the PBL as a teaching method, expand the pedagogical approaches to optimize the acquisition of knowledge. The use of technological resources such as quiz, realistic simulation, scientific presentations, films are reported in several articles as successful experiences regarding the meaningful learning of medical contents (Dias-Lima et al., 2019; Acosta et al., 2019; Gotardelo et al., 2017).

The "Brain Quiz and Games" activity approached contents in advance, therefore being considered as previous organizers, so that anchor points were created in the cognitive structure of the students in order to serve as subsumers of the later stage, where the contents were covered in the tutorials.

The objective is to report the application of quizzes and games called "Brain Quiz and Games".

\section{Method}

\subsection{Research Design}

The Brain Quiz and Games was applied in the Perception, Awareness and Emotion module of the Medical School of the Mato Grosso do Sul State University (UEMS), located in the state of Mato Grosso do Sul, central region of Brazil, which uses the PBL (Problem Based Learning) method.

The Perception, Awareness and Emotion module took place from July 26 to September 21, 2016, occurring two tutorial sessions per week for opening and closing problems. The module's program comprises the following contents: higher mental functions organization; Central Nervous System (CNS) development, structure and bioelectric operation correlation; brain understanding as the integrating organ of psychic operation and as a relationship intermediary with the world.

\subsection{Research Process}

The "Brain Quiz and Games" activity consisted of three meetings (in the second, third and fourth week of the module), overtime of tutoring activities. In these meetings, the students received the activity material to be developed. During the Quiz, the students answered the questions individually, in the brain games, the students answered the proposed questions in groups, competing with other teams, thus stimulating the agile and logical reasoning, so necessary for a good medical practice. The dates of the activities were chosen considering the fact that the students would not have yet discussed the contents in tutoring, acting as previous organizers.

In total, there were four activities, two in the form of brain quiz and two in the form of brain games. The first quiz consisted of 35 multiple choice questions (example of the questions used in Figure 1), referring to the most diverse contents encompassed in the field of neurophysiology and neuroanatomy, pillars of the module. The students answered the questions within two hours individually. At the end of this time, the coordinating professor gave a feedback of the questions, 


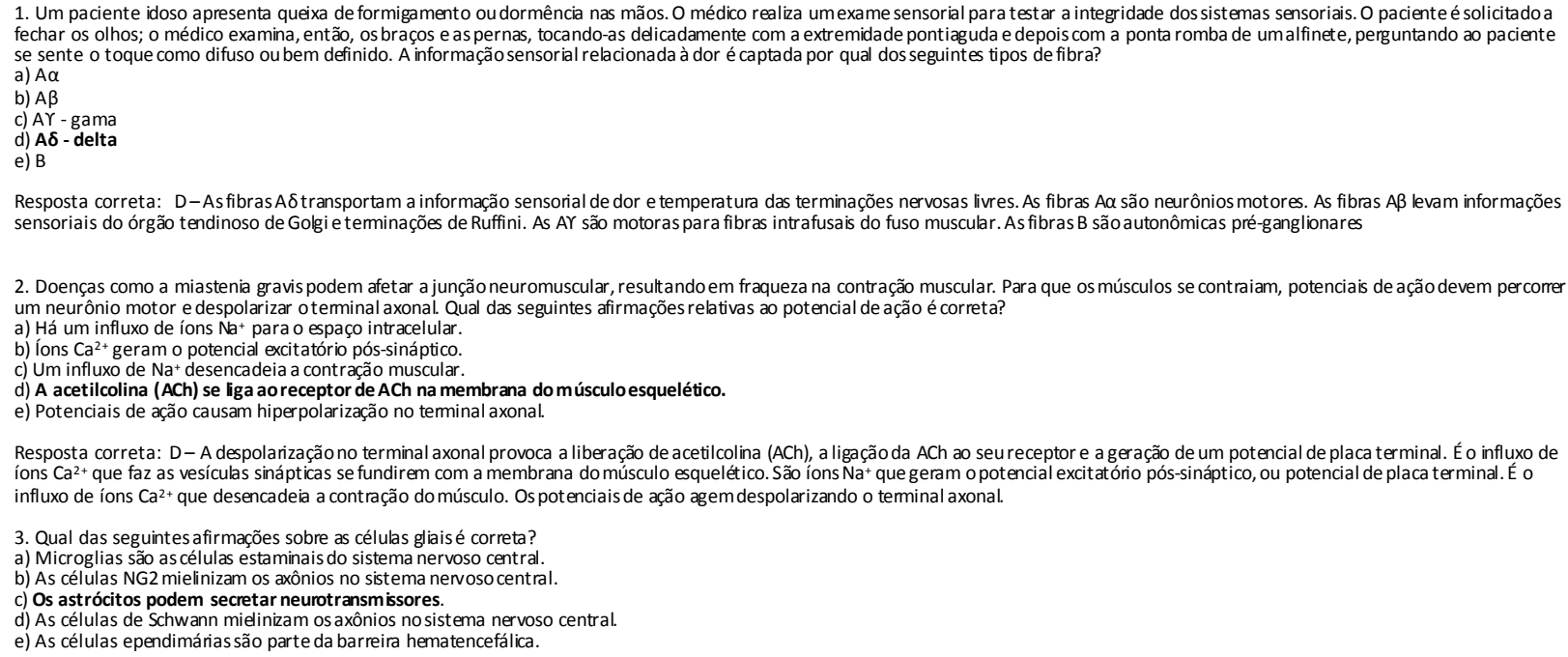

Resposta correta: C - as células NG2, e não a micróglia, são a reserva de células-tronco do cérebro. As oligodendroglias mielinizamos axônios no sistema nervoso central, e as células de Schwanno fazem no sistema nervoso periférico. Os astrócitos podem secretar neurotransmissores na fenda sináptica e assim, modular a atividade naquela sinapse. Epêndima é o epitélio dos ventrículos.

Figura 1. Exemplo de questões utilizadas na atividade do Quiz do cérebro (Livro Neurociências ilustradas, KREBS, C.; WEINBERG, J.; AKESSON, E., 2013).

explaining each alternative. The second quiz consisted of 30 questions, and the procedures were similar to the first.

The Brain Games were in number of two, and unlike the quiz, they were performed in groups of eight students, consisting in a competition between six groups. The questions of the games were elaborated with pictures (example of the questions used in Figure 2 and Figure 3) and blanks to be fulfilled with the answers. The games lasted 30 minutes and could be ended earlier if any group completed in advance. In each game, there were eight pictures, each with several blanks. At the end, the groups delivered their answers in poster boards, and the coordinating professor of the module corrected them and released a final classification of the groups.

The activities were presented individually and to each student group at the same time. The first group to complete all questions should speak immediately; the others should interrupt their work until the module coordinator checked the answers. If the group did not reach at least $80 \%$ of correct answers, the professor would correct the second group to have finished the activities and so on. The group with the most hits, in most activities, was the winner.

\subsection{Analysis Method}

The results of the application of Quis and Gymkhana were subjectively analyzed by the researchers, by collecting the individual feedbacks from the students who participated in the activity, as well as through the researchers' own perception.

There is no information in the article so I can write that ex-plan how the results were analyzed. I assume it was the evaluator's perception and individual student feedback. 

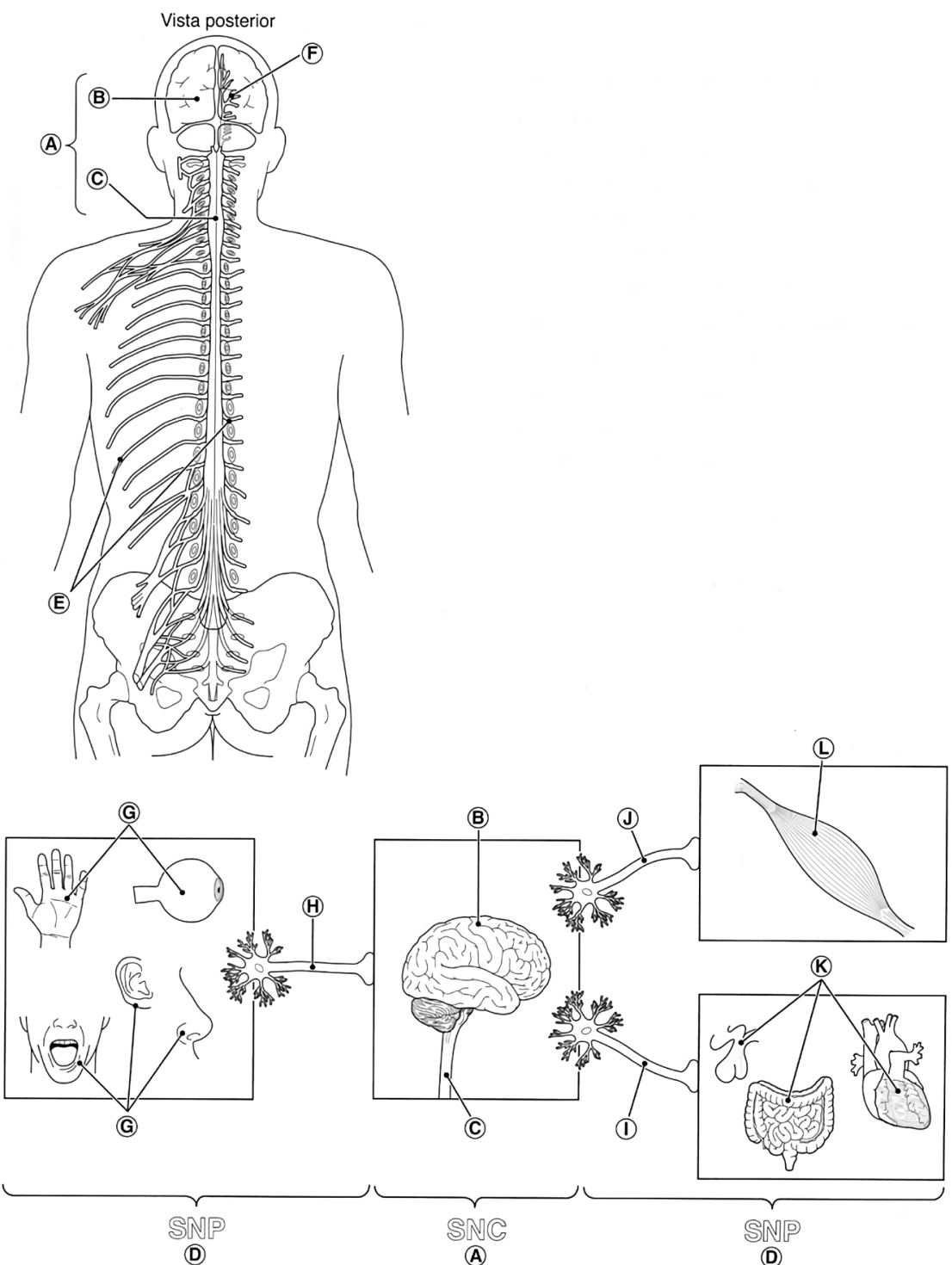

Figura 2. Exemplo de questão da gincana do cérebro (Livro Neurociências ilustradas, KREBS, C.; WEINBERG, J.; AKESSON, E., 2013).

\section{Results}

The application of the "Brain Quiz and Games" activity was a pioneer in the program and was attended by the 48 medical students enrolled in the 4 th semester.

A great achievement was the fact that students participated in these activities before discussing the contents in the tutorials. In other words, they started the tutorials of each subject with a prior consolidated knowledge, only needing to be refined by the depth with which the topics are discussed in the tutorial groups.

The feedback from the students was done informally, indicating the approval of this activity in order to assist the learning of the module contents. It can even be inferred that the good performance of most of the class in the final grades of the module confirms the importance of such activities for the consolidation of learning. 

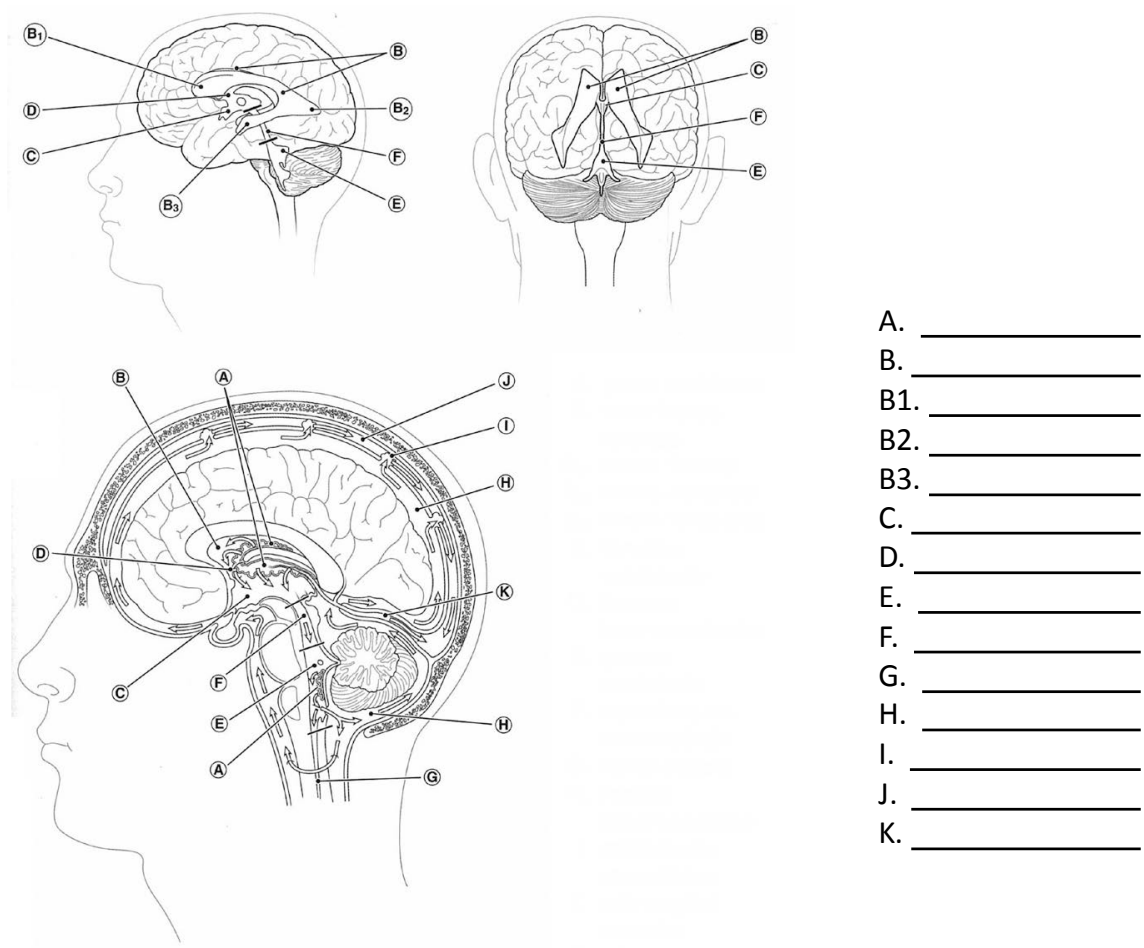

Figura 3. Exemplo de questão da gincana do cérebro (Livro Neurociências ilustradas, KREBS, C.; WEINBERG, J.; AKESSON, E., 2013).

The major difficulty perceived was the organization of the students to fulfill the answer blanks, as there were opinion discrepancies, and each student fulfilled the gaps with "their own words". In fact, this corroborates Ausubel's postulates, making knowledge more productive and showing non-arbitrary and substantive learning, because medicine is not an exact science. Besides that, the physician must learn to work in a team, to be a leader, to be critical, reflective and ethical, as the current NCG of medical schools advocate.

\section{Discussion}

The students showed interest and were engaged in participating in the activity, which was performed overtime to the other activities of the module.

The knowledge was acquired with problem-solving skills as quickly as possible and with the support of colleagues from different groups. In a world with increasing technological advancement, teaching-learning innovations change work, communication, daily life and thinking too, emerging new needs to rethink the way of teaching, learning and living a profession (Gomes \& Rego, 2011).

For these methodologies to have an effect in the direction of intentionality, it is necessary that process participants assimilate, understand, believe in their pedagogical potential and include the intellectual availability and appreciation of the proposal, therefore the student engagement is the essential condition for exercising freedom and autonomy in decisions (Berbel, 2011). 
For the elaboration of new pedagogical proposals, the undergraduate programs, and especially those in the health area, have been encouraged to include, in their reorganizations, teaching methodologies that allow them to cope with the new profiles outlined for their professionals. It is possible to understand that these methodologies are based on forms to develop the learning process, using real or simulated experiences, aiming at the conditions to successfully solve the challenges arising from academic and professional practice (Berbel, 2011).

The viable alternatives and interesting possibilities for finding new meaningful educational tools for students should be based on the commitment to learning and training professionals, if possible, in a playful manner (Silva, Canedo, Abrantes, Souza, Santos, \& Utagawa, 2009).

Regarding this assessment of the methodology, it is noteworthy that the present learning conception is associated with the idea of content fixation, but this is a benefit to both the acquisition of information and the development of competences (Dalton \& Bueno, 2010).

The previous knowledge stands out for its organization, clarity and stability, and influences the meaningful acquisition of new knowledge, in an interactive process in which the new gains meanings, integrating and differentiating the relationship from something already existing. Thereby the information is more stable, differentiated, rich, and able to anchor and consolidate knowledge at a time. The previous organizer is an instructional resource presented at a higher level of abstraction, generality and inclusiveness regarding to the learning material (Moreira, 2013).

Some studies corroborate the results found from this experience, considering that they refer to the application of the Quiz in medical teaching practices as a new complementary teaching tool, which can be constantly updated and directed to the difficulties encountered, and it reinforces the idea that educators should consider combining other teaching strategies for knowledge building (Silva, Canedo, Abrantes, Souza, Santos, \& Utagawa, 2010).

\section{Conclusion}

The literature review showed that previous organizers are useful strategies to achieve a meaningful learning. Introductory materials prepared the ground for new information incoming, activating memories, concepts and knowledge, so that anchor points were created in the cognitive structure of the students in order to serve as subsumers of the later stage, where the contents were covered in the tutorials. For this experiment, it was applied the "Brain Quiz and Games" activity, as a previous organizer, in the Perception, Awareness and Emotion module of the Medical School of the Mato Grosso do Sul State University (UEMS), from July 26 to September 21, 2016. Forty-eight medical students enrolled in the 4 th semester attended the event. During the quiz, the students answered the questions individually; in the brain games, the students answered the proposed questions in groups, competing with other teams. At the end, the coordinating 
professor gave a feedback of the questions, explaining each alternative. The activity enabled the students to start the tutorials of each subject with a prior consolidated knowledge. The blanks were fulfilled with the students' word, corroborating Ausubel's postulates.

The use of previous knowledge organizers in medical education should be encouraged and can be applied to both traditional and active teaching-learning methodologies. In the case of this experience, as the program uses active methodologies, the activity developed of "Brain Quiz and Games" stimulated the advance study of the module content and the creation of subsumers in the students' cognitive structure.

Although there was no formal assessment of the application of the activity, the students' informal reports, the grade of the cognitive tests and the final grade of the module reflected on a good use of the class in general.

Creative activities supported by learning theories that promote student autonomy provide a more consolidated and meaningful medical education.

\section{Conflicts of Interest}

The authors declare no conflicts of interest regarding the publication of this paper.

\section{References}

Acosta, L. A. M., Castellanos, M. R. P., Arias, M. L., Alcivar, O. A. C., \& Ronquillo, G. M. C. (2019). Teorias pedagógicas que apoiam a aprendizagem com o uso de tecnologias de informação e comunicação. Revista Información Cientifica, 98, 244-255.

Agra, G., Formiga, M. S., Oliveira, P. S., Costa, M. M. L., Fernandes, M. G. M., \& Nóbrega, M. M. L. (2017). Análise do conceito de Aprendizagem Significativa à luz da Teoria de Ausubel. Revista Brasileira de Enfermagem, 72, 258-265.

Ausubel, D. P., Novak, J. D., \& Hanesian, H. (1980). Psicologia educacional (Transl. by Eva Nick et al.). Rio: Interamericana.

Berbel, N. A. N. (2011). As Metodologias Ativas e a Promoção da Autonomia de Estudantes. Semina: Ciências Sociais e Humanas, 32, 25-40. https://doi.org/10.5433/1679-0383.2011v32n1p25

Brasil (2014). Ministério da Educação. Câmara de Educação Superior. Resolução no 3, de 20 de junho de 2014. Institui Diretrizes Curriculares Nacionais do Curso de Graduação em Medicina e dá outras providências. Brasília, Diário Oficial da União, 23 de junho de 2014.

Daltro, M. R., \& Bueno, G. (2010). Ludicidade e Narrativa: Estratégias de Humanização na Graduação Médica. Revista Brasileira de Educação Médica, 34, 497-505. https://doi.org/10.1590/S0100-55022010000400004

Dantas, C., \& Rodrigues, C. C. (2013). Estratégias metacognitivas como intervenção psicopedagógica para o desenvolvimento do automonitoramento. Revista Psicopedagogia, 30, 226-235.

Dias-Lima, A., Silva, M. C., Ribeiro, L. C. V., Bendicho, M. T., Guedes, H. T. V., \& Lemaire, D. C. (2019). Avaliação, Ensinagem e Metodologias Ativas: Uma Experiência Vivenciada no Componente Curricular Mecanismos de Agressão e de Defesa. Revista Brasileira de Educação Médica, 43, 216-224. 
https://doi.org/10.1590/1981-52712015v43n2rb20180037

Gomes, A. P., \& Rego, S. (2011). Transformação da Educação Médica: É Possível Formar um Novo Médico a partir de Mudanças no Método de Ensino-Aprendizagem? Revista Brasileira de Educação Médica, 35, 557-566. https://doi.org/10.1590/S0100-55022011000400016

Gotardelo, D. R., Bollela, V. R., Souza, A. P. G., Barros, D. P., Balbino, J. M. V., \& Ballester, D. (2017). Role-Play Preceded by Fieldwork in the Teaching of Pharmacology: From "Raw Sap" to "Elaborated Sap". Revista Brasileira de Educação Médica, 41, 533-539. https://doi.org/10.1590/1981-52712015v41n3rb20160043

Moreira, M. A. (2013). Aprendizagem significativa, organizadores prévios, mapas conceituais, diagramas e unidades de ensino potencialmente significativas. Porto Alegre: Instituto de Física da UFRGS, 1-24.

http://www.if.ufrgs.br/ moreira/apsigsubport.pdf

Moreira, M. A., \& Masini, E. F. S. (1982). Aprendizagem significativa: A teoria de David Ausubel. São Paulo: Moraes.

Moreira, M. A., Caballero, M. C., \& Rodriguez, M. L. (1997). Aprendizagem significativa: Um conceito subjacente. In M. A. Moreira, M. C. Caballero, \& M. L. Rodríguez (Eds.), Actas del Encuentro Internacional sobre el Aprendizaje Significativo (pp. 19-44). Burgos: UFRGS. http://www.if.ufrgs.br/ moreira/apsigsubport.pdf

Ribeiro, R. J., Silva, S. C. R., \& Koscianski, A. (2012). Organizadores prévios para aprendizagem significativa em Física: O formato curta de animação. Revista Ensaio, 14, 167-183. https://doi.org/10.1590/1983-21172012140311

Silva, J. M. A., Canedo, R. V., Abrantes, T. A. S., Santos, R. T., Souza, R. A., \& Utagawa, C. Y. (2010). Quiz: Um Questionário Eletrônico para Autoavaliação e Aprendizagem em Genética e Biologia Molecular. Revista Brasileira de Educação Médica, 34, 607-614. https://doi.org/10.1590/S0100-55022010000400017

Silva, J. M. A., Canedo, R. V., Abrantes, T. A. S., Santos, R. T., Souza, R. A., \& Utagawa, C. Y. (2009). Quiz de Genética e Biologia Molecular-A experiência discente e docente no desenvolvimento de um material didático. Cadernos UniFOA, 11, 65-68.

Taylor, D. C. M., \& Handy, H. (2013). Adult Learning Theories: Implications for Learning and Teaching in Medical Education: AMEE Guide No. 83. Medical Teacher, 35, e1561-e1572. https://doi.org/10.3109/0142159X.2013.828153 